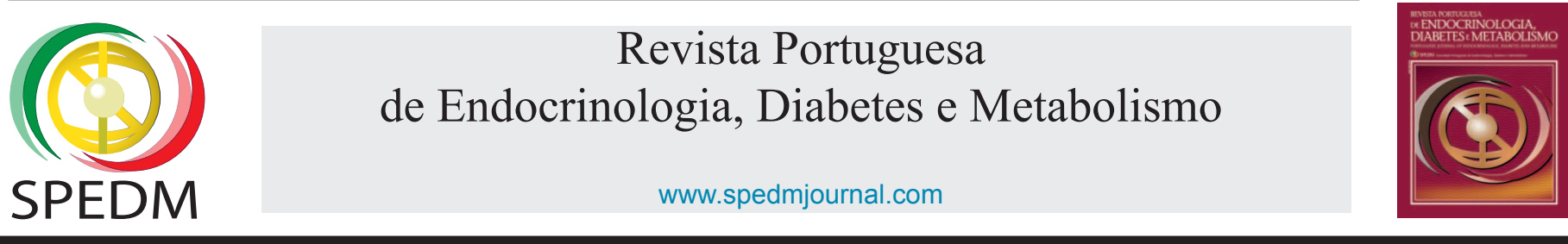

Caso Clínico

\title{
A Rare Case of Hypergonadotrophic Hypogonadism by 47,XXY/46,XX Mosaicism
}

\author{
Catarina Chaves ${ }^{\mathrm{a},}$, , Filipe Manuel Cunha ${ }^{\mathrm{a}}$, Daniela Coelho ${ }^{\mathrm{b}}$, Margarida Silva Vieira ${ }^{\mathrm{a}}$, \\ Susana Garrido ${ }^{a}$, Mariana Martinho ${ }^{a}$, Margarida Almeida ${ }^{a}$ \\ ${ }^{a}$ Serviço de Endocrinologia / Centro Hospitalar do Tâmega e Sousa, Penafiel, Portugal \\ ${ }^{b}$ Unidade de Saúde Familiar Hygeia / Agrupamento de Centros de Saúde Vale do Sousa Norte, Lixa, Portugal
}

\section{INFORMAÇÃO SOBRE O ARTIGO}

\section{Historial do artigo:}

Received/ Recebido: 2020-04-15

Accepted/Aceite: 2020-10-05

Final: 2021-01-19

(C) Autor (es) (ou seu (s) empregador (es)) Revista SPEDM 2020. Reutilização permitida de acordo com CC BY-NC. Nenhuma reutilização comercial.

C) Author(s) (or their employer(s)) and SPEDM

Journal 2020. Re-use permitted under CC BY-NC.

No commercial re-use.

Keywords:

Klinefelter Syndrome

\section{A B S T R A C T}

Klinefelter syndrome represents the most common cause of hypergonadotrophic hypogonadism. The presence of a 47, XXY / 46, XX mosaicism with male phenotype and characteristics of Klinefelter syndrome has been reported in less than a dozen cases. We report a case of a patient with Klinefelter syndrome phenotype presenting as a 47, XXY / 46, XX mosaicism discovered while investigating male primary infertility. The analytical study revealed hypergonadotrophic hypogonadism and the testicular ultrasound displayed diminished testicular volumes. The peripheral blood lymphocytes karyotype revealed mos: 46, XX [10] / 47, XXY [40].
Palavras-chave:

Síndrome de Klinefelter

\section{Um Caso Raro de Hipogonadismo Hipergonadotrófico por Mosaico 47,XXY/46,XX}

R E S U M O

A síndrome de Klinefelter é a alteração congénita causadora de hipogonadismo hipergonadotrófico mais comum. A presença de um mosaico 47, XXY / 46, XX com fenótipo masculino e características de síndrome de Klinefelter foi reportada em menos de uma dezena de casos até à data. Apresentamos um caso de um doente com fenótipo de síndrome de Klinefelter em mosaicismo 47, XXY / 46, XX descoberto por infertilidade primária masculina. Do estudo realizado destaca-se a nível analítico a presença de hipogonadismo hipergonadotrófico, a ecografia testicular revelou testículos de tamanho diminuído e o cariótipo realizado em linfócitos do sangue periférico, onde foram estudadas 50 metafases mostrou: $\operatorname{mos} 46, \mathrm{XX}[10] / 47, \mathrm{XXY}[40]$.

\footnotetext{
* Autor Correspondente / Corresponding Author.

E-Mail: catarinarchaves@gmail.com (Catarina Chaves)

Avenida do Hospital Padre Américo, № 210

4560-136 Guilhufe - Penafiel, Portugal
} 


\section{Introduction}

Klinefelter syndrome (KS), characterized by the presence of an additional $\mathrm{X}$ chromosome, represents the most common cause of hypergonadotrophic hypogonadism, with an estimated prevalence of 1:500 to 1:1000 men. ${ }^{1,2}$ Eighty percent present with a 47, XXY karyotype and the remaining 20\% present with a 47, XXY / $46, X Y$ mosaicism or with multiple $\mathrm{X}$ chromosome aneuploidies, often with additional $\mathrm{Y}$ chromosomes. ${ }^{3,4} \mathrm{KS}$ is severely underdiagnosed or is diagnosed late in life..$^{5}$ Its most relevant clinical features are diminished and firm testicles, infertility $\backslash a z o o s p e r m i a$, tall stature, eunuchoidism, gynecomastia, and osteoporosis. ${ }^{4-7}$ The clinical presentation may, however, be extremely variable. The phenotype correlates with the severity of genetic abnormalities and the effects of the hypogonadism. ${ }^{2,5,7}$ Generally, the higher the number of supernumerary $\mathrm{X}$ chromosomes, the worse the phenotype. Less severe genetic alterations, such as mosaicism, usually result in less exuberant clinical manifestations. ${ }^{7}$

Patients with KS have increased morbidity and mortality, with a decrease of approximately 2 years in average life expectancy, due to various disorders such as diabetes, pulmonary pathologies, epilepsy, cerebrovascular disease and vascular insufficiency of the intestine. $^{2}$

The treatment of KS is based on testosterone supplementation therapy to alleviate the consequences of hypogonadism as well as on the prevention and treatment of comorbidities. ${ }^{4-7}$

The presence of a $47, \mathrm{XXY} / 46, \mathrm{XX}$ mosaicism is extremely rare and this mosaicism with male phenotype and characteristics of KS has been reported in only eight cases..$^{8-15}$ In addition, several other phenotypes associated with this mosaicism have been described including female phenotype or anomaly of ovotesticular sexual differentiation. ${ }^{16-20}$ We report a case of a patient with KS phenotype presenting as a 47, XXY / 46, XX mosaicism discovered while investigating male primary infertility.

\section{Case Report}

We report a 53-year-old Caucasian with a male phenotype. He worked as a house-builder and had a primary school degree. $\mathrm{He}$ was referred to the Endocrinology department because of gynecomastia and infertility. His past medical history was significant for epilepsy, degenerative discopathy, and varicose vein surgery and was chronically medicated with valproic acid and bioflavonoids. There was no history of infertility, genetic syndromes or known endocrinopathies in the family.

At the age of 28, he was already investigated for infertility. The analytical study revealed hypergonadotrophic hypogonadism and the spermogram revealed azoospermia. Due to non-attendance to the appointment, he lost the follow-up and was not supplemented with testosterone. On physical examination, the patient had a male phenotype, a eunuchoid habitus (height of $180 \mathrm{~cm}$, armspan of $186 \mathrm{~cm}$ ), weighed $75 \mathrm{~kg}$ and had a body mass index of $23 \mathrm{~kg} /$ $\mathrm{m}^{2}$. He had a scarce beard, adipomastia, normally located external urinary meatus and bilaterally diminished, firm testicles, without masses.

Baseline laboratory data were: free testosterone $1.51 \mathrm{pg} / \mathrm{mL}$ (6.60-30.00), LH 14.0 mIU/mL (1.2-8.6), FSH 60.9 mIU/mL (1.319.3), hemoglobin $13.5 \mathrm{~g} / \mathrm{dL}$ (13.9-16.3), hematocrit $42.6 \%$ (39.055.0 ), glucose $86 \mathrm{mg} / \mathrm{dL}, \mathrm{HbAlc} 5.2 \%$, total cholesterol $168 \mathrm{mg} /$ $\mathrm{dL}$, HDL $51 \mathrm{mg} / \mathrm{dL}, \mathrm{LDL} 105 \mathrm{mg} / \mathrm{dL}$, triglyceride $60 \mathrm{mg} / \mathrm{dL}, \mathrm{TSH}$ $2.54 \mathrm{mIU} / \mathrm{mL}(0.38-5.33)$, calcium $9 \mathrm{mg} / \mathrm{dL}$ (8.6-10.2), 25-OHvitamin D $77 \mathrm{nmol} / \mathrm{L}$ (insufficient $<50$ ), phosphor $3.5 \mathrm{mg} / \mathrm{dL}$
(2.7-4.5), alkaline phosphatase 82 IU/L (34-104), PTH 58 pg/mL and prostatic-specific antigen $0.42 \mathrm{ng} / \mathrm{mL}(<4.00)$. The testicular ultrasound displayed diminished testicular volumes (right testicle $2.6 \mathrm{~mL}$ and left testicle $3.2 \mathrm{~mL}$ ). The breast ultrasound showed adipomastia and the bone densitometry osteopenia ( $\mathrm{T}$ score in the lumbar spine of -1.7 , and in the femoral neck of -1.7). The electrocardiogram was normal, with regular rhythm, rate $72 \mathrm{bpm}$, normal axis, presence of $\mathrm{p}$ waves, QRS complex with $90 \mathrm{~ms}$, QT interval with $370 \mathrm{~ms}$ and ST segment without pathological changes. The thorax radiography showed no suspicious pulmonary opacities, no focal areas of consolidation, heart size within normal limits and no pleural effusions.

The peripheral blood lymphocyte karyotype revealed mos: 46, XX [10] / 47, XXY [40] which confirmed the diagnosis of Klinefelter syndrome (Fig. 1). He was started on testosterone enanthate intramuscular $250 \mathrm{mg}$ supplementation, every 3 weeks with normalization of testosterone values and witout adverse effects. $\mathrm{He}$ maintained normal hematocrit $43 \%$ and stable prostatic-specific antigen value with $0.51 \mathrm{ng} / \mathrm{mL}$ one year after.

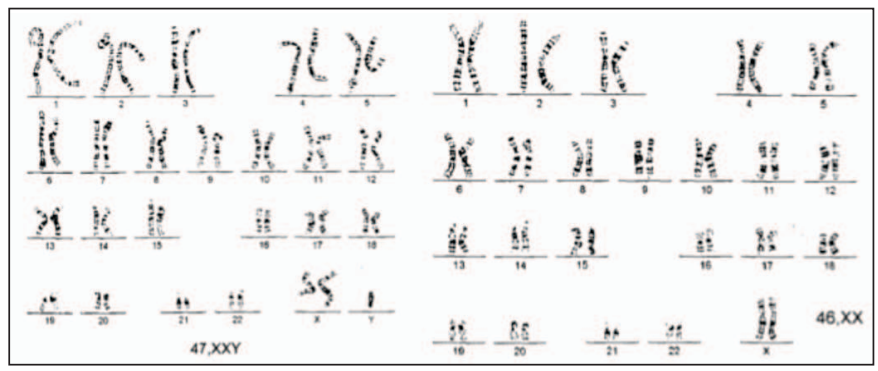

Figure 1. Peripheral blood lymphocyte karyotype: mos: 46, XX [10] / 47, XXY [40]

\section{Discussion}

$\mathrm{KS}$ is not uncommon, although its subtle clinical manifestation until puberty might be the reason it still highly underdiagnosed. In some cases, such as the present clinical report, $\mathrm{KS}$ is only diagnosed in adult patients. A karyotype must be performed whenever KS is suspected. . $^{2,4}$

From all other case reports of the presence of a 47, XXY/46, $\mathrm{XX}$ mosaicism with male phenotype and characteristics of $\mathrm{KS}$, the majority were detected at the pediatric age, and only two were diagnosed during adulthood. ${ }^{8-15}$ One was diagnosed during an infertility study, just as described in this case report, at the age of 29 , and the other was diagnosed in the context of a teratoma at the age of $62 .^{12,13}$

The most interesting aspect of this case had to do with the patient karyotype, which showed a mosaicism with cell lines 46, XX and 47, XXY. The genetic explanation for the occurrence of KS is based on a failure in the disjunction of the sex chromosome in the meiosis, which leads to the presence of an extra X chromosome..$^{7,13}$ Mosaicism occurs in about $20 \%$ of KS patients and results from non-disjunction in an early mitotic division of the developing 46, XY zygote or the loss of one of the X chromosomes of a 47, XXY design due to anaphase delay. ${ }^{7,13}$ In patients with mosaicism, the resulting phenotype depends on the proportion of the two different cell lines in the various tissues of the developing embryo. ${ }^{21}$

Gonadal phenotype and phenotypic sex are influenced by the proportion and distribution of the Y chromosome in the gonads, which does not always correspond to the proportion of these cells 
in peripheral blood. ${ }^{13,22,23}$ Thus, if at the level of gonads Y chromosome cells predominate, the phenotype will correspond to the male sex, this is explained by the effect of SRY gene expression above a critical level. ${ }^{13,24}$

In this case, we have no data on the patient's gonadal karyotype, but given the phenotype, it can be suspected that most gonadal cells will have a Y chromosome leading to male sexual differentiation.

There are very few reported cases of KS patients with a 47, $\mathrm{XXY} / 46, \mathrm{XX}$ mosaicism, perhaps due to the underestimation of these cases.13 Failure to detect 46, XX cell line in routine blood cytogenetic investigation or, in the case of prenatal diagnosis, misdiagnose the 46, XX cell line along with the 47, XXY cells as maternal contamination may explain the rarity of this presentation. ${ }^{13}$

There are still not enough known cases to clarify if the clinical course of patients with mosaicism 47, XXY / 46, XX is in some matter different from the other mosaicisms associated KS, so a similar follow-up should be maintained just like in other patients with KS. Patients with KS need lifelong follow-up with monitoring and supplementation of testosterone, as well as management of prevention and / or treatment of comorbidities. ${ }^{4-7}$ Patients with $\mathrm{KS}$ are associated with an increased risk of developing malignancy, especially mediastinal germinal cell tumors, which makes follow-up of these patients even more important. ${ }^{14,25}$

\section{Conclusion}

The presence of patients with 47, XXY / 46, XX mosaicism is extremely rare, perhaps due to its underdiagnosis. The phenotype in these patients is influenced by the percentage of gonadal Y chromosome cells, but more cases are needed to understand if these patients have a different clinical evolution compared to other mosaicism associated KS.

\section{Responsabilidades Éticas}

Conflitos de Interesse: Os autores declaram a inexistência de conflitos de interesse na realização do presente trabalho.

Fontes de Financiamento: Não existiram fontes externas de financiamento para a realização deste artigo.

Confidencialidade dos Dados: Os autores declaram ter seguido os protocolos da sua instituição acerca da publicação dos dados de doentes.

Consentimento: Consentimento do doente para publicação obtido.

Proveniência e Revisão por Pares: Não comissionado; revisão externa por pares.

\section{Ethical Disclosures}

Conflicts of Interest: The authors have no conflicts of interest to declare.

Financing Support: This work has not received any contribution, grant or scholarship.

Confidentiality of Data: The authors declare that they have followed the protocols of their work center on the publication of data from patients.

Patient Consent: Consent for publication was obtained.

Provenance and Peer Review: Not commissioned; externally peer reviewed.

\section{References / Referências}

1. Gardner R, Amor D. Chromosome Abnormalities and Genetic Counseling. 4th ed. Oxford: Oxford University Press; 2018.

2. Lanfranco F, Kamischke A, Zitzmann M, Nieschlag E. Klinefelter's syndrome. Lancet. 2004;364:273-83. doi: 10.1016/S0140-6736(04)16678-6.

3. Forti G, Corona G, Vignozzi L, Krausz C, Maggi M. Klinefelter's syndrome: a clinical and therapeutical update. Sex Dev. 2010;4:249-58. doi: $10.1159 / 000316604$.

4. Melmed S, Polonsky KS, Larsen PR, Kronenberg HM. Williams textbook of endocrinology. 13th ed. Amsterdam: Elsevier;2016.

5. Groth KA, Skakkebæk A, Høst C, Gravholt CH, Bojesen A. Clinical review: Klinefelter syndrome--a clinical update. J Clin Endocrinol Metab. 2013;98:20-30. doi: 10.1210/jc.2012-2382.

6. Calogero AE, Giagulli VA, Mongiò̀ LM, Triggiani V, Radicioni AF, et al. Klinefelter syndrome: cardiovascular abnormalities and metabolic disorders. J Endocrinol Invest. 2017;40:705-12. doi: 10.1007/s40618017-0619-9.

7. Bonomi M, Rochira V, Pasquali D, Balercia G, Jannini EA, Ferlin A, et al. Klinefelter syndrome (KS): genetics, clinical phenotype and hypogonadism. J Endocrinol Invest. 2017;40:123-34. doi: 10.1007/ s40618-016-0541-6.

8. Ford CE, Polani PE, Briggs JH, Bishop PM. A presumptive human XXY/ XX mosaic. Nature. 1959;183:1030-2. doi: 10.1038/1831030a0.

9. Crooke A, Hayward M. Mosaicism in klinefelter's syndrome. Lancet.1960; 275:1198.

10. Nowakowski H, Lenz W, Bergman S, Reitalu J. Chromosome findings in true Klinefelter syndrome. Acta Endocrinol. 1960;34:483-95.

11. Hecht F, Antonius JI, McGuire P, Hale CG. XXY cells in a predominantly XX human male: evidence for cell selection. Pediatrics. 1966; 38:982-5.

12. Matsuki S, Sasagawa I, Kakizaki H, Suzuki Y, Nakada T. Testicular teratoma in a man with XX/XXY mosaic Klinefelter's syndrome. J Urol. 1999;161:1573-4.

13. Velissariou V, Christopoulou S, Karadimas C, Pihos I, Kanaka-Gantenbein $\mathrm{C}$, et al. Rare XXY/XX mosaicism in a phenotypic male with Klinefelter syndrome: case report. Eur J Med Genet. 2006;49:331-7. doi: 10.1016/j. ejmg.2005.09.001.

14. Song JS, Lee SH, Jin DK, Kim SH. A case report of rare XXY/ $\mathrm{XX}$ mosaicism in a phenotypic male with Klinefelter syndrome and mediastinal germ cell tumor. Genet Couns. 2014;25:215-20.

15. Mohd Nor NS, Jalaludin MY. A rare $47 \mathrm{XXY} / 46 \mathrm{XX}$ mosaicism with clinical features of Klinefelter syndrome. Int J Pediatr Endocrinol. 2016;2016:11. doi: 10.1186/s13633-016-0029-3.

16. Bergmann M, Schleicher G, Böcker R, Nieschlag E. True hermaphroditism with bilateral ovotestis: a case report. Int J Androl. 1989;12:139-47. doi: 10.1111/j.1365-2605.1989.tb01297.x.

17. Nihoul-Fékété C, Lortat-Jacob S, Cachin O, Josso N. Preservation of gonadal function in true hermaphroditism. J Pediatr Surg. 1984;19:50-5. doi: $10.1016 / \mathrm{s} 0022-3468(84) 80015-9$.

18. Pérez-Palacios G, Carnevale A, Escobar N, Villareal G, Fernandez C, Medina M. Induction of ovulation in a true hermaphrodite with male phenotype. J Clin Endocrinol Metab. 198152:1257-9. doi: 10.1210/jcem52-6-1257

19. Gagnon J, Leboeuf G, Ducharme JR. Hypoplasie ovarienne primitive 'a formule gonosomique sanguine XX-XXY. Union Med Can. 1965;94:974-84.

20. Hamlett JD, Timson J, Harris R. XX-XXY mosaicism in a phenotypically normal female. Hum Hered. 1970;20:260-4. doi: 10.1159/000152319.

21. Robinson WP, McFadden DE, Barrett IJ, Kuchinka B, Peñaherrera MS, Bruyère H, Best RG, Pedreira DA, Langlois S, Kalousek DK. Origin of amnion and implications for evaluation of the fetal genotype in cases of mosaicism. Prenat Diagn. 2002;22:1076-85. doi: 10.1002/pd.483.

22. Kelly TE, Franko JB, Rogol A, Golden WL. Discordant phenotypes and 45,X/46,X,idic(Y). J Med Genet. 1998;35:862-4. doi: 10.1136/ jmg.35.10.862.

23. Kelly TE, Franko JB, Rogol A, Golden WL. Discordant phenotypes and 45,X/46,X,idic(Y). J Med Genet. 1998;35:862-4. doi: 10.1136/ jmg.35.10.862.

24. Quilter CR, Nathwani N, Conway GS, Stanhope R, Ralph D, Bahadur G, et al. A comparative study between infertile males and patients with Turner syndrome to determine the influence of sex chromosome mosaicism and the breakpoints of structurally abnormal Y chromosomes on phenotypic sex. J Med Genet. 2002;39:e80. doi: 10.1136/jmg.39.12.e80.

25. Talreja SM, Banerjee I, Yadav SS, Tomar V. A rare case of lateral ovotesticular disorder with Klinefelter syndrome mosaicism 46, XX/47, XXY: An unusual presentation. Urol Ann. 2015;7:520-3. doi: 10.4103/0974-7796.164855. 